\title{
How Many Words Does a Picture Really Tell? Cross-sectional Descriptive Study of Pictogram Evaluation by Youth
}

\author{
Artyom Korenevsky, Régis Vaillancourt, Annie Pouliot, Marine Revol, Evan Steed, Luc Besançon, \\ Marit-Saskia Wahrendorf, and Jaimisha R Patel
}

\begin{abstract}
Background: Communicating health-related instructions with pictograms is useful, but such graphics can be interpreted in different ways. It is crucial to understand which pictogram components are best for accurate communication.

Objectives: To catalogue pictograms used to label drugs in clinical practice; to identify the common graphic elements for defined categories of pictograms, by performing a semiotic analysis (studying how signs are perceived and how they should be designed); to identify the key graphic elements common to pictograms preferred by users; and to develop suggestions for future pictogram design on the basis of users' input.
\end{abstract}

Methods: Literature and Internet searches were performed to identify pictograms and pictogram categories. A call for pictograms was also circulated through the International Pharmaceutical Federation (FIP). Youth at a Canadian pediatric hospital were asked to rate pictograms (including storyboards and prescription labels generated by FIP pictogram software) in terms of how best they represented their intended meanings. Pictograms for which at least $80 \%$ of participants "somewhat agreed", "agreed", or "strongly agreed" that the graphic conveyed the intended meaning were designated as "preferred" and were selected for analysis. Elements appearing in at least $50 \%$ of these preferred pictograms were highlighted as key graphic elements for design of future pictograms.

Results: In total, 21 categories were identified for pictograms used in clinical practice, and a total of 204 pictograms were analyzed. Eighty-six participants took part in the survey. For each pictogram category, certain elements were identified as "preferred" and as "key graphic elements", whereas other elements met neither designation. For all 21 pictogram categories, at least $80 \%$ of survey respondents agreed that the FIP storyboard conveyed the intended meaning.

Conclusions: Certain key, preferred graphic elements are required for pharmaceutical pictograms to convey their intended meaning. The overlap between preferred and key pictogram elements indicates that both must be considered in development of future pictograms. Redesign of existing pictograms with consideration of the best semiotic elements is in progress.

Keywords: semiotics, semiology, medication literature

\section{RÉSUMÉ}

Contexte : La communication des instructions concernant la santé à l'aide de pictogrammes est utile, mais ces graphiques peuvent être interprétés de différentes façons. Il est crucial de connaittre quels éléments de ces pictogrammes sont les plus adéquats pour permettre une communication précise.

Objectifs : Répertorier les pictogrammes utilisés pour étiqueter les médicaments en pratique clinique; déterminer les éléments graphiques courants pour chaque catégorie de pictogrammes, en effectuant une analyse sémiotique (étude de la perception des signes et de leur représentation graphique); définir les éléments graphiques clés communs aux pictogrammes préférés des usagers; et formuler des suggestions pour la conception de futurs pictogrammes en tenant compte des commentaires des usagers.

Méthodes: Une recherche bibliographique et une recherche dans Internet ont été menées pour déterminer les pictogrammes et les catégories de pictogrammes. Une demande de soumission de pictogrammes a aussi été diffusée par l'entremise de la Fédération internationale pharmaceutique (FIP). Dans un hôpital pour enfants du Canada, on a demandé à des jeunes d'évaluer les pictogrammes (y compris des étiquettes de médicaments prescrits et des scénarios illustrés générés par le logiciel de pictogrammes de la FIP) quant à l'exactitude de leur représentation du message qu'on voulait livrer. Les pictogrammes pour lesquels au moins $80 \%$ des participants étaient " plutôt d'accord ", " d'accord " ou " tout à fait d'accord " que le graphique livrait le message voulu ont été jugés comme étant " préférés " et retenus aux fins d'analyse. Les éléments apparaissant dans au moins 50\% des pictogrammes préférés ont été sélectionnés comme éléments graphiques clés pour la conception de futurs pictogrammes.

Résultats : En tout, 21 catégories de pictogrammes utilisés dans la pratique clinique ont été déterminées, 204 pictogrammes ont été analysés et 86 participants ont répondu au sondage. Pour chaque catégorie de pictogrammes, certains éléments ont été définis comme étant " préférés » et comme des "éléments graphiques clés ", alors que d'autres éléments n'ont satisfait ni l'une ni l'autre de ces désignations. Pour les pictogrammes de l'ensemble des 21 catégories, au moins $80 \%$ des répondants ont affirmé que le scénario illustré généré par le logiciel de la FIP communiquait le message qu'on voulait livrer.

Conclusions : Certains éléments graphiques clés et préférés sont requis afin que les pictogrammes pharmaceutiques communiquent le message qu'on veut livrer. Le chevauchement entre les éléments graphiques préférés et les éléments graphiques clés indiquent que les deux doivent être pris en compte dans la création de futurs pictogrammes. La reconception des pictogrammes existants qui tient compte des meilleurs éléments sémiotiques est en cours.

Mots clés : sémiotique, sémiologie, documentation sur les médicaments

[Traduction par l'éditeur] 


\section{INTRODUCTION}

W

ith the increasing use of prescription drugs, the accurate

communication of medication instructions is becoming even more critical for ensuring proper and safe use. ${ }^{1,2}$ Approaches involving only written information directed to individual patients have been criticized for using language that is difficult to interpret. ${ }^{3,4}$ Therefore, tools such as pamphlets, brochures, calendars, and diagrams, with limited reliance on text, have been increasingly used to educate patients about their medications. Over the past 5 years, the Military and Emergency Pharmacy Section of the International Pharmaceutical Federation (FIP) has convened to develop a practical approach to pictograms, such as using software to generate pictograms during humanitarian medical missions. Their work led to the suggestion to use "storyboards" (graphic organization in the form of multiple illustrations displayed in sequence; see http://vps22221.public.cloudvps.com/home) to convey medication instructions to patients.

Humans have attempted to communicate with symbols for thousands of years, and the use of pictures to convey messages has evolved to the modern pictogram. ${ }^{5,6} \mathrm{~A}$ pictogram is not just any symbol; rather, it conveys a very specific message and meaning. ${ }^{6}$ Pharmaceutical pictograms improve recall by acting as visual cues. ${ }^{7-9}$ This use of pictograms has been shown to improve patients' understanding of health information presented on prescription labels and in information leaflets. ${ }^{7 ., 10-13}$ However, some articles in the literature do not support such benefits. ${ }^{14-17}$ The literature is contradictory in other ways. For example, some authors suggest that in populations with relatively high literacy, adding a pictogram to written instructions may introduce confusion rather than clarity. ${ }^{14}$ Other authors have strongly suggested that pictograms should be accompanied by supporting text and/or verbal instructions. ${ }^{18}$

In the design of pictograms, it is possible that certain elements are effective in conveying meaning, while others are not. To the authors' knowledge, no previous publications have addressed the topic of "pictogram grammar" or the conventions to follow when designing a medical pictogram for optimal understanding. More specifically, the components of medication-related pictograms that are essential to meaning and the elements that fall short of conveying the message effectively have not been compared. Such analyses fall within the field of semiotics, a subdiscipline of linguistics that studies what signs consist of and the specific rules that govern how signs are perceived and how they should be designed. ${ }^{19}$ According to Ferdinand de Saussure, who made important contributions to the study of semiotics, a sign can be divided into 2 parts: the signified (a concept or object) and the signifier (a sound or image attached to the signified). Semiotic research is used to analyze text, layout, and illustrations to acquire a deeper understanding of how these parts are interpreted by members of society. ${ }^{20}$ Simply put, semiotics can be thought of as the interface between design and interpretation.

We hypothesized that, by dissecting pictograms into their individual semiotic components, we would be able to establish components of preference, which could then be used to design better-understood pictograms. Therefore, by conducting a semiotic review of medication-related pictograms, we aimed to identify evidence-based, scientifically validated components for the construction of future pictograms, in the hope that such initiatives would improve patients' understanding of and compliance with their medications.

The specific objectives were to catalogue pictograms used to label drugs in clinical practice; to identify the common graphic elements for defined categories of pictograms, by performing a semiotic analysis (studying how signs are perceived and how they should be designed); to identify the key graphic elements common to pictograms preferred by users; and to develop suggestions for future pictogram design on the basis of patients' input.

\section{METHODS}

\section{Search for Pictograms}

A convenience sample of 21 categories of medicationrelated pictograms was selected for evaluation: take with water, take with food, take on an empty stomach, do not take with alcohol, keep in refrigerator, shake before use, keep out of reach of children, do not take when pregnant, do not take when breastfeeding, take 1 tablet, take 2 tablets, ear drops, eye drops, for rectal use only, for topical use only, take in the morning, take at night, take 3 times daily, inhale using an inhaler device, use an inhaler with a spacer device, and do not drive when taking this medication.

Three methods were used to search for pictograms: literature search, Internet search, and direct e-mail request. The literature search, using Embase, PubMed, PubMed Central, Scopus, Google Scholar, and Google Images, was performed by a pharmacy student (A.K.) and reviewed by the principal investigator (R.V). Journal articles containing pictograms were scanned manually to ensure inclusion of all pictograms. The following words and synonyms (individually and in combination) were used for both the literature and online searches: "pictograms", "pictographs", "pictorial images", "symbols and diagrams", "pharmaceutical pictograms", "medication labels", "auxiliary labels", "warning labels", "line drawings", and "icons". A request to share pictograms relevant to the project was sent by e-mail to the membership of the Military and Emergency Pharmacy Section of FIP. 


\section{Inclusion and Exclusion Criteria}

Only pictograms intended for use in clinical practice in either pediatric or adult populations (or both) were retained for evaluation. Pictograms from the following sources were included in the evaluation:

- articles published in English or French medical journals within the past 25 years (up to January 2012)

- online sources of auxiliary or warning labels

- patient information leaflets

- member organizations of FIP

Pictograms illustrating single-step or multistep instructions were included. Validation of pictograms was noted, along with the country or community that performed the validation, if available (see Table 1). In total, 39 sources of pictograms were identified. The sources were subdivided into 3 types: organizations, publications, or online (Internet).
Pictograms not intended for use in clinical practice or for professional use, those depicting the use of illicit drugs, and those using computer animations of the images were excluded.

\section{Semiotic Analysis}

Each pictogram was analyzed for its component graphic features. The analysis began with description of the individual component features of each pictogram, which was performed by the primary author (A.K.) and checked by the principal investigator (R.V). The component features were then compiled to create a table of the semiotic components in all 21 pictogram categories. These elements were independently reviewed by 2 researchers (E.S., M.R), and differences of opinion were resolved through discussion among all members of the project team. Elements that appeared in at least $50 \%$ of all pictograms within a category were considered to represent "common graphic elements" for that category. Elements that

Table 1. Categories of Pictograms and Sources* (part 1 of 2)

\begin{tabular}{|c|c|c|c|}
\hline Pictogram Category & $\begin{array}{l}\text { o. of Pictograms } \\
\text { Foundt }\end{array}$ & Countries of Use or Validation¥ & Sources of Pictograms \\
\hline Take with water & 14 & $\begin{array}{l}\text { Australia (aboriginal community), Canada, } \\
\text { China, Gabon, Haiti, Japan, Malawi, Mexico, } \\
\text { Niger, South Africa, Tanzania, USA }\end{array}$ & $\begin{array}{l}\text { Organization }(n=5) \\
\text { Publication }(n=3) \\
\text { Internet }(n=6)\end{array}$ \\
\hline Take with food & 13 & $\begin{array}{l}\text { Australia (aboriginal community), Canada, } \\
\text { Canada (First Nations), China, Gabon, Haiti, } \\
\text { Japan, Malawi, Mexico, Niger, South Africa, } \\
\text { Tanzania, USA }\end{array}$ & $\begin{array}{l}\text { Organization }(n=5) \\
\text { Publication }(n=2) \\
\text { Internet }(n=6)\end{array}$ \\
\hline Take on an empty stomach & 5 & Australia, Canada, Canada (First Nations) & $\begin{array}{l}\text { Publication }(n=2) \\
\text { Internet }(n=3)\end{array}$ \\
\hline Do not take with alcohol & 15 & $\begin{array}{l}\text { Australia (aboriginal community), Canada, } \\
\text { Canada (First Nations), China, Gabon, Haiti, } \\
\text { Japan, Malawi, Mexico, Niger, South Africa, } \\
\text { Tanzania, USA }\end{array}$ & $\begin{array}{l}\text { Organization }(n=5) \\
\text { Publication }(n=6) \\
\text { Internet }(n=4)\end{array}$ \\
\hline Keep in refrigerator & 10 & $\begin{array}{l}\text { Australia (aboriginal community), Canada, } \\
\text { Canada (First Nations), China, Japan, } \\
\text { South Africa, Tanzania, USA }\end{array}$ & $\begin{array}{l}\text { Organization }(n=1) \\
\text { Publication }(n=3) \\
\text { Internet }(n=6)\end{array}$ \\
\hline Shake before use & 11 & $\begin{array}{l}\text { Australia (aboriginal community), Canada, } \\
\text { Canada (First Nations), China, Japan, } \\
\text { South Africa, Tanzania, USA }\end{array}$ & $\begin{array}{l}\text { Publication }(n=4) \\
\text { Internet }(n=7)\end{array}$ \\
\hline Keep out of reach of children & 14 & $\begin{array}{l}\text { Australia (aboriginal community), Canada, } \\
\text { Canada (First Nations), China, Japan, } \\
\text { South Africa, Tanzania, USA }\end{array}$ & $\begin{array}{l}\text { Organization }(n=1) \\
\text { Publication }(n=5) \\
\text { Internet }(n=8)\end{array}$ \\
\hline Do not take when pregnant & 14 & $\begin{array}{l}\text { Australia (aboriginal community), Canada, } \\
\text { Canada (First Nations), China, Japan, } \\
\text { South Africa, Tanzania, USA }\end{array}$ & $\begin{array}{l}\text { Organization }(n=2) \\
\text { Publication }(n=7) \\
\text { Internet }(n=5)\end{array}$ \\
\hline Do not take when breastfeeding & 6 & Canada, Canada (First Nations), China, USA & $\begin{array}{l}\text { Organization }(n=2) \\
\text { Publication }(n=1) \\
\text { Internet }(n=3)\end{array}$ \\
\hline Take 1 tablet & 5 & $\begin{array}{l}\text { Canada, Canada (First Nations), China, Gabon, } \\
\text { Haiti, Malawi, Niger }\end{array}$ & $\begin{array}{l}\text { Organization }(n=2) \\
\text { Internet }(n=3)\end{array}$ \\
\hline Take 2 tablets & 5 & $\begin{array}{l}\text { Canada, Canada (First Nations), China, Gabon, } \\
\text { Haiti, Malawi, Niger }\end{array}$ & $\begin{array}{l}\text { Organization }(n=2) \\
\text { Internet }(n=3)\end{array}$ \\
\hline Ear drops & 14 & $\begin{array}{l}\text { Australia (aboriginal community), Canada, } \\
\text { Canada (First Nations), Japan, South Africa, } \\
\text { USA }\end{array}$ & $\begin{array}{l}\text { Organization }(n=4) \\
\text { Publication }(n=4) \\
\text { Internet }(n=6)\end{array}$ \\
\hline
\end{tabular}


Table 1. Categories of Pictograms and Sources* (part 2 of 2)

\begin{tabular}{|c|c|c|c|}
\hline Pictogram Category & $\begin{array}{l}\text { No. of Pictograms } \\
\text { Foundt }\end{array}$ & Countries of Use or Validation¥ & Sources of Pictograms \\
\hline Eye drops & 13 & $\begin{array}{l}\text { Australia (aboriginal community), Canada, } \\
\text { Canada (First Nations), Japan, South Africa, } \\
\text { USA }\end{array}$ & $\begin{array}{l}\text { Organization }(n=7) \\
\text { Publication }(n=4) \\
\text { Internet }(n=2)\end{array}$ \\
\hline For rectal use only & 7 & China, South Africa, USA & $\begin{array}{l}\text { Organization }(n=2) \\
\text { Publication }(n=3) \\
\text { Internet }(n=2)\end{array}$ \\
\hline For topical use only & 6 & China & $\begin{array}{l}\text { Organization }(n=1) \\
\text { Publication }(n=1) \\
\text { Internet }(n=4)\end{array}$ \\
\hline Take in the morning & 9 & $\begin{array}{l}\text { Canada, Canada (First Nations), Gabon, Haiti, } \\
\text { Japan, Malawi, Niger, USA }\end{array}$ & $\begin{array}{l}\text { Organization }(n=2) \\
\text { Publication }(n=1) \\
\text { Internet }(n=6)\end{array}$ \\
\hline Take at night & 15 & $\begin{array}{l}\text { Canada, Canada (First Nations), Gabon, Haiti, } \\
\text { Japan, Malawi, Niger, USA }\end{array}$ & $\begin{array}{l}\text { Organization }(n=8) \\
\text { Publication }(n=3) \\
\text { Internet }(n=4)\end{array}$ \\
\hline Take 3 times daily & 8 & Canada, Canada (First Nations), Japan, USA & $\begin{array}{l}\text { Organization }(n=3) \\
\text { Publication }(n=1) \\
\text { Internet }(n=4)\end{array}$ \\
\hline Inhale using an inhaler device & 5 & $\begin{array}{l}\text { Australia (aboriginal community), Canada, } \\
\text { Canada (First Nations), USA }\end{array}$ & $\begin{array}{l}\text { Organization }(n=2) \\
\text { Publication }(n=1) \\
\text { Internet }(n=2)\end{array}$ \\
\hline $\begin{array}{l}\text { Use an inhaler with a } \\
\text { spacer device }\end{array}$ & 5 & Australia (aboriginal community) & $\begin{array}{l}\text { Organization }(n=1) \\
\text { Publication }(n=4)\end{array}$ \\
\hline $\begin{array}{l}\text { Do not drive when taking } \\
\text { this medication }\end{array}$ & 10 & $\begin{array}{l}\text { Australia (aboriginal community), Canada, } \\
\text { Canada (First Nations), France, Japan, USA }\end{array}$ & $\begin{array}{l}\text { Organization }(n=1) \\
\text { Publication }(n=2) \\
\text { Internet }(n=7)\end{array}$ \\
\hline
\end{tabular}

*Complete chart of pictograms is available by request to the authors.

†Excluding prescription label and storyboard generated by International Pharmaceutical Federation software.

fListed in alphabetical order for each pictogram category.

appeared in at least $50 \%$ of the pictograms for which at least $80 \%$ of participants agreed that the pictogram conveyed its intended meaning (as described in the next section) were considered to represent "key graphic elements" for that category. Agreement was defined to include responses of "somewhat agree", "agree", and "strongly agree". The $80 \%$ cut-off was based on guidelines from the European Commission. ${ }^{11}$

\section{Recruitment of Participants for Survey}

Adolescents between the ages of 12 and 18 years were recruited from outpatient clinics, waiting rooms, the emergency department, and the volunteer organization of the Children's Hospital of Eastern Ontario (CHEO) in Ottawa, Ontario, as well as from a youth organization at the hospital. Potential participants were eligible if they spoke and read English with sufficient proficiency to complete the survey. The following demographic and clinical information was collected: age, sex, grade school level (or highest level of education completed), and number of different types of medications taken regularly (including vitamins, minerals, supplements, and inhalers). Data collection for the study was approved by the hospital's Research Ethics Board.

\section{Survey}

The survey was divided into 5 parts, each covering 4 or 5 pictogram categories. The estimated time to complete the entire survey was 1 hour. To reduce the time required for participation, each respondent was asked to complete just 1 of the 5 parts of the survey, although respondents were given the opportunity to complete more than one part (or even the entire survey) if desired.

The pictograms in each category were grouped together within the survey. At the beginning of each category, a written statement asked the respondent whether the written meaning of the pictogram category was represented by each pictogram within the category. For example, for the category "do not drive when taking this medication", respondents were asked "Do the pictograms below mean 'do not drive when taking this medication'?" The respondents were asked to respond to this question for each pictogram within the category using a 5-point Likert scale (disagree, somewhat disagree, somewhat agree, agree, and strongly agree). In addition, each category included the pertinent storyboard and prescription label generated by the pictogram software of the FIP. These softwaregenerated items incorporated a pictogram relevant to the 
specific category, as well as other pictograms representing the written instructions on the storyboard and the prescription label. The survey data were collected and entered into SPSS 20 software (IBM, Armonk, New York) for further statistical and descriptive analysis.

\section{RESULTS}

\section{Catalogue of Pictograms}

A total of 204 pictograms were collected for the 21 pictogram categories (details in Table 1; chart of all pictograms and their sources is available by request to the authors). Overall, 56 (27\%) of the 204 pictograms were collected from organizations such as the FIP and the United States Pharmacopeial Convention, 57 (28\%) from scientific journals and other publications, and 91 (45\%) from the Internet.

\section{Common Pictogram Elements}

Appendix 1 (available online at http://www.cjhp-online. ca/index.php/cjhp/issue/view/94/showToc) presents the most common elements in each pictogram category, i.e., the semiotic elements found in over $50 \%$ of pictograms in each category.

\section{Preferred Pictogram Elements}

A total of 86 participants took part in the survey, and there were at least 25 responses per pictogram category $(n=27$ for survey sets A, C, and D; $n=26$ for survey set B; $n=25$ for survey set E). Ten of the participants completed all 5 parts of the survey; the remaining participants each completed 1 or 2 of the 5 parts. Just over half of the participants were male ( 44 [51\%]). Participants' ages ranged from 12 to 18 years (mean \pm standard deviation $15.2 \pm 1.6$ years; 42 [49\%] were under 16 years of age and 44 [51\%] were 16 or older). Twenty-eight participants $(33 \%)$ reported that they did not take any medications on a regular basis, 38 (44\%) reported taking at least one medication regularly, and 20 (23\%) either did not respond to the question or indicated something other than a number in the answer field.

The semiology was further refined, as presented in Table 2 , which shows elements that were common to at least $50 \%$ of the pictograms for which at least $80 \%$ of survey respondents "somewhat agreed", "agreed", or "strongly agreed" that the graphic conveyed the intended meaning. These "preferred" elements were considered to be the minimum key elements for design of a pictogram that would be well understood.

Notably, the storyboard generated by FIP software met the $80 \%$ selection criterion for all 21 categories of pictograms (average agreement $84.1 \%$ ). The prescription label generated by FIP software met the $80 \%$ selection criteria for 11 of the pictogram categories. No relationship was found between the number of elements in a pictogram and its average agreement rating.

\section{DISCUSSION}

To the authors' knowledge, this study is the first of its kind to assess the semiotic components of medication-related pictograms. Previous studies have evaluated preferences related to and comprehension of entire pictograms, and some researchers have attempted to break down the graphic components of pictograms, but none have done so within a specified target population. ${ }^{7,8,11,17,20}$

The results of the current study indicate that some graphic elements in pictograms are preferred over others. However, despite complex statistical analysis, no simple trend or pattern was readily observed. For example, the number of individual elements in some categories surpassed 50, even without taking minor elements into account. Shading, intermediate colours, and colour brightness were not reviewed in this analysis. In addition, only basic shapes were considered. Size, angles, line thickness, empty space, and many other aspects of the pictograms were not examined.

Although many elements appeared in at least $50 \%$ of pictograms in a category (i.e., the "common" elements), the pictograms that met the respondent selection criteria contained different elements (i.e., the "preferred" elements). Thus, when designing pictograms, it is not sufficient to rely on the most common graphic elements; other elements must also be considered in the creation of a well-understood pictogram.

The presence of written text in some pictograms appeared to increase respondents' preference for those pictograms. This might be partly explained by the presence of a general written statement of meaning at the beginning of each pictogram category in the survey. For example, respondents were asked questions like "Do the pictograms below mean 'do not take with alcohol'?" As such, any impact of a written element within the pictogram might have been overshadowed by this statement. It is hoped that a similar study will be conducted in the future, without explanatory text at the beginning of each part of the survey, to examine the impact of written instructions on respondents' understanding of the pictograms. Data on age and grade level indicate that most of the participants were enrolled in high school. According to the Canadian Council on Learning, ${ }^{21}$ adults with at least high school education have better health literacy than adults with less education.

We also considered whether the source of the pictograms might have had an impact on preference, but found no such connection. It should be noted that the pictogram-selection process created a certain bias for the analysis. By their nature, medication-related pictograms are similar to one another. The design process varies between organizations, yet may involve copying and then slightly modifying established pictograms or auxiliary labels. Consequently, the presence of groups of very similar pictograms within a category may have skewed the 
Table 2. Key Elements of Pictograms* (part 1 of 2)

\begin{tabular}{|c|c|c|c|}
\hline Pictogram Category & $\begin{array}{l}\text { Pictograms } \\
\text { elected }\end{array}$ & $\begin{array}{c}\text { No. of } \\
\text { Participants }\end{array}$ & Key Semiotic Elements \\
\hline Take with water & 8 & 26 & $\begin{array}{l}\text { A face is shown in side profile, with an open mouth, forehead, } \\
\text { nose, chin, and neck; a glass of water is tilted toward the mouth; } \\
\text { pills and capsules are present. The pictogram is in black and white. }\end{array}$ \\
\hline Take with food & 5 & 26 & $\begin{array}{l}\text { Utensils (fork and/or knife and/or spoon and/or chopsticks) and a } \\
\text { plate holding food are shown with medication tablets. The } \\
\text { pictogram is in black and white. }\end{array}$ \\
\hline Take on an empty stomach & 3 & 25 & $\begin{array}{l}\text { A stomach is outlined, with the word "empty" on the stomach. } \\
\text { The pictogram is in colour, with a rectangle around the pictogram. }\end{array}$ \\
\hline Do not take with alcohol & 9 & 27 & $\begin{array}{l}\text { Martini and/or wine and/or beer glasses are shown with a slash } \\
\text { through them. The pictogram is in black and white with a square } \\
\text { or circle around the entire pictogram. }\end{array}$ \\
\hline Keep in refrigerator & 5 & 26 & $\begin{array}{l}\text { A 3D refrigerator is shown, with one door on top of the other; the } \\
\text { refrigerator door should be open, with food items such as juice, } \\
\text { fruit, and jars shown inside; an arrow is shown extending from the } \\
\text { pill container to the refrigerator. The pictogram is in colour (blue), } \\
\text { with a square around the medication and the refrigerator. }\end{array}$ \\
\hline Shake before use & 9 & 27 & $\begin{array}{l}\text { A medication bottle for liquids is shown vertically with a label; a } \\
\text { hand ( } 4 \text { fingers and a thumb) is holding the bottle; lines outside } \\
\text { the bottle indicate movement. The pictogram is in colour. }\end{array}$ \\
\hline Keep out of reach of children & 7 & 27 & $\begin{array}{l}\text { An outline of a toddler with a diaper is shown next to a pill } \\
\text { container with loose capsules; the toddler is reaching toward the } \\
\text { medication; a cross appears over these components. The pictogram } \\
\text { is in black and white, with a circle around the pictogram. }\end{array}$ \\
\hline Do not take when pregnant & 8 & 26 & $\begin{array}{l}\text { A dark, solid silhouette of a naked pregnant woman is shown, } \\
\text { with one arm visible; a slash appears through the silhouette. The } \\
\text { pictogram is in black and white, with a rectangle around the entire } \\
\text { pictogram. }\end{array}$ \\
\hline Do not take when breastfeeding & 1 & 26 & $\begin{array}{l}\text { A 3D image of a woman breastfeeding is shown; the woman has } \\
\text { no hair, is naked, and is holding the baby at her breast in one arm; } \\
\text { a medication bottle with a capsule is also shown; a cross appears } \\
\text { over both components. The pictogram is in black and white with } \\
\text { a circle around the entire pictogram. }\end{array}$ \\
\hline Take 1 tablet & 4 & 25 & $\begin{array}{l}\text { A face is shown in side profile, with the forehead, nose, eye, } \\
\text { mouth, and chin visible; one oversized tablet is shown; an arrow } \\
\text { connects the tablet and the mouth. The pictogram is in black and } \\
\text { white, with a square around the entire pictogram. }\end{array}$ \\
\hline Take 2 tablets & 4 & 26 & $\begin{array}{l}\text { A face is shown in partial side profile, including eyes, nose, open } \\
\text { mouth, chin, and lips; } 2 \text { tablets are shown, with an arrow } \\
\text { connecting the tablets and the mouth. The pictogram is in black } \\
\text { and white, with a square around the entire pictogram. }\end{array}$ \\
\hline Ear drops & 8 & 27 & $\begin{array}{l}\text { One ear is shown; the medication is represented as a bottle, with } \\
\text { one drop of medication going from the bottle into the ear; the } \\
\text { patient's hand is pulling down the ear. The pictogram is in black } \\
\text { and white with a square around the entire pictogram. }\end{array}$ \\
\hline Eye drops & 6 & 27 & $\begin{array}{l}\text { One eye, with pupil, is shown; one side of face, with eyebrow and } \\
\text { nose, is shown; an ophthalmic medication bottle is present, with } \\
\text { one drop coming out of the bottle; patient is pulling down the } \\
\text { eye with one hand. The pictogram is in black and white with a } \\
\text { square around the entire pictogram. }\end{array}$ \\
\hline For rectal use only & 2 & 27 & $\begin{array}{l}\text { The area between the waist and knees is shown, along with a } \\
\text { suppository; the action of inserting the suppository is indicated } \\
\text { with the patient's hand. The pictogram is in black and white with } \\
\text { a square around the entire pictogram. }\end{array}$ \\
\hline For topical use only & 4 & 27 & $\begin{array}{l}\text { A tube full of cream is shown, with cream coming out of the tube, } \\
\text { a hand with arrows showing the direction of rubbing, and cream } \\
\text { visible on the skin. The pictogram is in black and white with a } \\
\text { circle around the pictogram. }\end{array}$ \\
\hline
\end{tabular}


Table 2. Key Elements of Pictograms* (part 2 of 2)

\begin{tabular}{|c|c|c|c|}
\hline Pictogram Category & $\begin{array}{l}\text { Vo. of Pictograms } \\
\text { Selected }\end{array}$ & $\begin{array}{c}\text { No. of } \\
\text { Participants }\end{array}$ & Key Semiotic Elements \\
\hline Take in the morning & 4 & 26 & $\begin{array}{l}\text { A sun is shown, with rays appearing as lines; a clock showing } \\
\text { 7:00 AM is shown, with sun rays around the clock. The pictogram } \\
\text { is in colour (orange and yellow). }\end{array}$ \\
\hline Take at night & 6 & 26 & $\begin{array}{l}\text { Stars and crescent moon are shown, as well as a bed with pillows } \\
\text { and blankets; the bed has a headboard and is shown in side profile } \\
\text { The pictogram is in one colour, with a square around the entire } \\
\text { pictogram. }\end{array}$ \\
\hline Take 3 times daily & 4 & 26 & $\begin{array}{l}\text { A face is shown with an open mouth and medication (pill and/or } \\
\text { capsule visible), along with a hand being used to place the } \\
\text { medication in the mouth; } 3 \text { separate sections are shown, indicating } \\
3 \text { times of the day (sun rising, sun fully visible, and no sun with } \\
\text { crescent moon); the } 3 \text { sections should be separated, with one pill } \\
\text { per part. The pictogram is in either black and white or colour, with } \\
\text { a square around the entire pictogram and rectangles around each } \\
\text { subsection. }\end{array}$ \\
\hline Inhale using an inhaler device & $\mathrm{ce}$ & 25 & $\begin{array}{l}\text { A face is shown in side profile, with the nose, eyes, mouth, chin, } \\
\text { neck, and ear visible; an inhaler is present in the mouth; a hand is } \\
\text { holding the inhaler in a pinching position. The pictogram is in } \\
\text { black and white, with a square around the entire pictogram. }\end{array}$ \\
\hline $\begin{array}{l}\text { Use an inhaler with a } \\
\text { spacer device }\end{array}$ & 4 & 25 & $\begin{array}{l}\text { A side profile head, down to the shoulder, is shown with an open } \\
\text { mouth; the inhaler and spacer (Aerochamber style) are shown; the } \\
\text { spacer attaches to the mouth only and is shown between the } \\
\text { inhaler and the mouth; the hand is in a pinching position on the } \\
\text { inhaler with spacer. The pictogram is in black and white with no } \\
\text { surrounding shape. }\end{array}$ \\
\hline $\begin{array}{l}\text { Do not drive when } \\
\text { taking this medication }\end{array}$ & 4 & 26 & $\begin{array}{l}\text { A sedan is presented in side profile with a cross or circle-cross } \\
\text { through it; a face with an open mouth is also shown, along with } \\
\text { tablets in a hand in front of the mouth. The pictogram is in black } \\
\text { and white, with a square around the entire pictogram. }\end{array}$ \\
\hline
\end{tabular}

results. However, the authors tried to vary the pictogram sources for all categories, with items chosen from organizations, publications, or the Internet. In addition, some pictograms were not exclusive to one source, as certain websites could be considered to represent organizations and vice versa. Future research might include a review of available pictogram sources for health care practitioners.

\section{FIP Storyboard}

For every category of pictograms, the storyboard generated by the FIP software met the selection criteria. However, the corresponding prescription label met the selection criteria for only 11 of the pictogram categories. The storyboard and prescription label for each category have a complete set of instructions; this difference might therefore be explained by the fact that the storyboard had larger, more easily seen pictograms. Indeed, the size of a pictogram is an important factor, as concluded in previous studies. ${ }^{18}$

The consistency of preference for the FIP storyboard speaks to much more than the size of the image. The context in which pictograms are presented is important to their correct interpretation, ${ }^{22}$ as exemplified by categories that had few preferred pictograms ("take 1 tablet", "take with an empty stomach", "do not take if breastfeeding"). The storyboard was consistently preferred by at least $80 \%$ of survey participants. This is not surprising since placing a pictogram in a broader context intuitively leads one to expect better comprehension.

\section{Limitations}

This study gathered information about participants' selfreported (subjective) opinions; it did not assess the comprehension and recall of different clinical pictograms. A comprehension study might have yielded different results. Another limitation was the inclusion of only English-speaking participants in the survey. These factors limit the generalizability of the results to broader populations, especially international ones.

\section{CONCLUSIONS}

The results of this study indicate that the presence of 
certain elements confers preference over pictograms that do not contain such elements. As such, pictograms must be designed according to sound semiotic principles and subsequently tested in target populations to assess comprehension and to ensure improved health outcomes.

The current study provides a stepping stone toward more systematic, evidence-based medication-related pictograms. This research is being used to redesign existing pictograms and to design new ones, which will require validation in the intended target populations. In this study, only 21 categories of pictograms were analyzed. Many more medication-related pictograms exist, covering aspects such as side effects, indications for use, and dosage forms. This type of analysis should be applied to other sets of pictograms.

Finally, studies encompassing much larger samples would have greater statistical power. It is our hope that once pictograms are deconstructed in this manner, their semiotic elements can be brought together in an evidence-based manner to improve health literacy and, ultimately, health outcomes.

\section{References}

1. Davis TC, Federman AD, Bass PF 3rd, Jackson RH, Middlebrooks M, Parker RM, et al. Improving patient understanding of prescription drug label instructions. J Gen Intern Med. 2009;24(1):57-62.

2. Davis TC, Wolf MS, Bass PF 3rd, Thompson JA, Tilson HH, Neuberger $\mathrm{M}$, et al. Literacy and misunderstanding prescription drug labels. Ann Intern Med. 2006;145(12):887-94.

3. Estrada CA, Hryniewicz MM, Higgs VB, Collins C, Byrd JC. Anticoagulant patient information material is written at high readability levels. Stroke. 2000;31(12):2966-70.

4. D'Alessandro DM, Kingsley P, Johnson-West J. The readability of pediatric patient education materials on the World Wide Web. Arch Pediatr Adolesc Med. 2001;155(7):807-12.

5. Tijus C, Barcenilla J, de Lavalette BC, Meunier JG. The design, understanding and usage of pictograms. In: Alamargot D, Terrier P, Cellier JM, editors. Studies in writing. Volume 21: Written documents in the workplace. Amsterdam: Elsevier; 2007. p. 17-32.

6. Dowse R, Ehlers MS. Pictograms in pharmacy. Int J Pharm Pract. 1998; 6(2):109-18

7. Houts PS, Witmer JT, Egeth HE, Loscalzo MJ, Zabora JR. Using pictographs to enhance recall of spoken medical instructions II. Patient Educ Couns. 2001;43(3):231-42.

8. Houts PS, Bachrach R, Witmer JT, Tringali CA, Bucher JA, Localio RA. Using pictographs to enhance recall of spoken medical instructions. Patient Educ Couns. 1998;35(2):83-8.

9. Ngoh LN, Shepherd MD. Design, development, and evaluation of visual aids for communicating prescription drug instructions to nonliterate patients in rural Cameroon. Patient Educ Couns. 1997;31(3):245-61.

10. Dowse R, Ramela T, Browne SH. An illustrated leaflet containing antiretroviral information targeted for low-literate readers: development and evaluation. Patient Educ Couns. 2011;85(3):508-15.

11. Mansoor LE, Dowse R. Effect of pictograms on readability of patient information materials. Ann Pharmacother. 2003;37(7-8):1003-9.

12. Dowse R, Ehlers M. Medicine labels incorporating pictograms: do they influence understanding and adherence? Patient Educ Couns. 2005; 58(1):63-70.

13. Delp C, Jones J. Communicating information to patients: the use of cartoon illustrations to improve comprehension of instructions. Acad Emerg Med. 1996;3(3):264-70.

14. Hwang SW, Tram CQ, Knarr N. The effect of illustrations on patient comprehension of medication instruction labels. BMC Fam Pract. 2005;6(1):26.
15. Morrell RW, Park DC, Poon LW. Effects of labeling techniques on memory and comprehension of prescription information in young and old adults. $J$ Gerontol. 1990;45(4):P166-72.

16. Wolf MS, Davis TC, Bass PF, Curtis LM, Lidquist LA, Webb JA, et al. Improving prescription drug warnings to promote patient comprehension. Arch Intern Med. 2010;170(1):50-6.

17. Dowse R, Ehlers MS. The evaluation of pharmaceutical pictograms in a low-literate South African population. Patient Educ Couns. 2001;45(2): 87-99.

18. Knapp P, Raynor DK, Jebar AH, Price SJ. Interpretation of medication pictograms by adults in the UK. Ann Pharmacother 2005;39(7-8):1227-33.

19. Chandler D. Semiotics for beginners. Self-published; 1994 [cited 2013 Feb 11]. Available from: http://users.aber.ac.uk/dgc/Documents/S4B/sem01.html

20. Thibault P. Re-reading Saussure: the dynamics of signs in social life. London (UK): Routledge; 1996.

21. Murray TS, Hagey J, Willms D, Shillington R, Desjardins R. Health literacy in Canada: a healthy understanding 2008. Ottawa (ON): Canadian Council on Learning; 2008.

22. Christen R. Pictogram 5.0: evolving the pictogram language [master's thesis]. Umeå (Sweden): Umeå University; 2007.

Artyom Korenevsky, BSc(Pharm), was, at the time of this study, a pharmacy student at the University of Waterloo, Waterloo, Ontario, on rotation with the Children's Hospital of Eastern Ontario, Ottawa, Ontario.

Régis Vaillancourt, PharmD, is with the Children's Hospital of Eastern Ontario, Ottawa, Ontario.

Annie Pouliot, PhD, is with the Children's Hospital of Eastern Ontario, Ottawa, Ontario.

Marine Revol is with the Children's Hospital of Eastern Ontario, Ottawa, Ontario.

Evan Steed, BSc(Pharm), was, at the time of this study, a pharmacy student at the University of Waterloo, Waterloo, Ontario, on rotation with the Children's Hospital of Eastern Ontario, Ottawa, Ontario.

Luc Besançon is with the International Pharmaceutical Federation.

Marit-Saskia Wahrendorf, PhD, is with Almspringer, Munich, Germany.

Jaimisha R Patel, MPharm, is with the Children's Hospital of Eastern Ontario, Ottawa, Ontario, and the University of Nottingham, Nottingham, United Kingdom.

Competing interests: Régis Vaillancourt receives payment as an elected member of the Council of the Ontario College of Pharmacists and serves as a volunteer surveyor for Accreditation Canada. He has grants pending from MedBuy, the World Health Organization, the International Pharmaceutical Federation, Algonquin College, Sandoz Canada, and Nycomed. He has received speaker's fees for a chronic pain presentation and related brochure from Purdue Frederick. Luc Besançon is the Acting General Secretary for Professional, Scientific and External Affairs with the International Pharmaceutical Federation. None declared for other authors.

\section{Address correspondence to:}

Dr Régis Vaillancourt

Children's Hospital of Eastern Ontario

401 Smyth Road

Ottawa ON K1H 8L1

e-mail: rvaillancourt@cheo.on.ca 